\title{
Information Literacy Competencies of Library and Information Science Postgraduate Students in South East Nigeria Universities: A Focus on the Knowledge and Skill Level
}

\author{
Dr. Chinwe Anunobi ${ }^{1}$ Obiora Kingsley Udem ${ }^{2}$ \\ 1.Federal University of Technology, OwerriImo State, Nigeria \\ 2.Nnamdi Azikiwe University Awka,Anambra State, Nigeria \\ * E-mail of the corresponding author: chiinobis@yahoo.com
}

\begin{abstract}
The study investigated the information literacy competencies possessed by Library and Information Science (LIS) postgraduate students in Federal Universities in South East Zone Nigeria with a focus on the Knowledge and skill level. Descriptive survey design was adopted for the study. Seventy two students which included all 2011/2012 PhD and Masters degree students from the Departments of LIS in Nnamdi Azikiwe University, Awka and University of Nigeria, Nsukka. Data was collected using Achievement Test and Questionnaire. Percentages, frequencies and mean rating were used to answer research questions. T-test was used to test hypotheses. The major findings of the study include: LIS postgraduate students in Federal Universities in South East Zone Nigeria possessed information literacy knowledge since the measure based on understanding the need for information, how to locate, evaluate and use information have average percentage scores of $95 \%, 87 \%, 82 \%$ and $88 \%$ respectively. However, the information literacy knowledge possessed by LIS Postgraduate students in Nnamdi Azikiwe University, Awka (NAU) differed significantly from those possessed by LIS Postgraduate students in University of Nigeria, Nsukka (UNN); LIS postgraduate students possessed moderate level of information literacy skills as their level of information literacy skills as measured based on ability to locate and access, evaluate and use information has general mean rating of 3.34. However, the skills differed significantly between LIS Postgraduate students in NAU and UNN. Based on the findings, it was recommended that more practical aspect of information literacy should be employed through students industrial training and internship, and LIS curriculum should be enhanced especially with reference to skill acquisition.
\end{abstract}

Keywords: Literacy, Competency, Skills, Knowledge , Nigeria , Library and Information Science, Nnamdi Azikiwe University Awka, University of Nigeria Nsukka, Students

\section{Introduction}

The advancement in information and communication technologies (ICT) has created a revolution in all spheres of knowledge. This revolution has become so obvious in information packaging and dissemination. Till later part of $20^{\text {th }}$ century, information from every source was packaged and disseminated on print platform (Anunobi \& Nwabueze, 2010). As a result of the nature of information packaging and dissemination in the $20^{\text {th }}$ century, students and scholars were depended on the print sources, but with changes in the $21^{\text {st }}$ century, they are faced with numerous electronic resources and databases. Individuals are faced with diverse, abundant information choices in their academic environment, workplace, and personal lives. Information is available through libraries, community resources centre, special interest groups, multiple media, as well as varying networks including the Internet. On daily basis people are bombarded with information emanating from the radio, television, newspapers, magazines, journals, books, email, wikis, facebook, twitters, etc.

As more information is available in diverse forms, information stakeholders need the knowledge and skills to find access and use it effectively. Although there has always been a need to find, evaluate, and effectively use information, the abilities needed to do so have grown larger, more complex, and more important in the ICT environment. Wilson (2001) opined that increasing attention to the need to find, access and effectively use information in recent years is partly the result of information overload, especially as it relates to the growth of digital information, which has even caused a new ailment termed "information fatigue syndrome".

The idea of developing skills and knowledge to find, access and use information effectively, which evolved in the early 1970s has grown, taken shape and strengthened to become recognized as the critical literacy for the $21^{\text {st }}$ century (Bruce, 2002). Library and Information Science (LIS) professionals have been in the forefront of teaching students the skills and knowledge needed to find, access and effectively use information as well as serving as information providers. As the environments of LIS professionals and academic libraries have changed, the abilities to find, access and effectively use information have also changed and broadened. What started as library orientation grew to be library instruction and bibliographic instruction and finally became information literacy. Shenton (2009) concluded that:

Information literacy has certainly expanded greatly in scope from its antecedents as user 
education or bibliographic instruction, which emphasized the exploitation of library tools, such as indexes, catalogues and classification schemes, and the use of particular types of sources, to expansive skills sets that are today permeated by a more widely applicable problem-solving perspective (p. 226).

Information literacy has been identified to include the capability of individuals to identify, locate and critically evaluate information for decision-making, knowledge creation and problem solving (Bruce, 2003; US National Commission on Library and Information Science, 2003). It encompasses the strategies, skills, knowledge and adoption of appropriate information behaviour needed to define information needs, and to locate, evaluate, synthesize, organize, use and communicate information in ethical manner (CILIP, 2004; Johnston \& Webber, 2003: SCONUL, 2011; Williams \& Coles, 2007). Information literacy therefore, may simply be defined as recognition of when and why information is needed, where to find it, how to access and evaluate, use and communicate it in an ethical manner.

The importance of Information literacy to students' success cannot be overemphasized. Information literacy as noted by University of Liverpool Learning and Teaching Committee (2007), allows students to develop the capacity for independent critical analysis that is the hallmark of a university education, and equips them with the capability to update their knowledge and skills after graduation. An information literate student is able to: recognize a need for information; determine the extent of information needed; access information efficiently; critically evaluate information and its sources; classify, store, manipulate and redraft information collected or generated; incorporate selected information into their knowledge base; use information effectively to learn, create new knowledge, solve problems and make decisions; understand economic, legal, social, political and cultural issues in the use of information; access and use information ethically and legally; use information and knowledge for participative citizenship and social responsibility; and experience information literacy as part of independent learning and lifelong learning (Bundy, 2004). These attribute of information literate individuals as listed by Bundy are expected from students in order to attain information literacy competency.

Competency according to Alberta Education (2010) has to do with knowledge, skills and attitude which are drawn upon and applied to a particular context for successful learning and living. European Communities (2007) defined key competencies for lifelong learning as a combination of knowledge, skills and attitude appropriate to the context. Based on the above definitions of competency and information literacy, information literacy competency therefore, has to do with knowledge, skills and attitude towards recognizing when and why information is needed, where to find and access it, how to evaluate, synthesize, use and communicate it ethically and legally. Library and Information Science (LIS) Postgraduate students are expected to possess all the attribute of information literacy.

LIS postgraduate students in Nigeria are students pursuing advanced study (Diploma, Masters or PhD Degree) in the Department of LIS. Those pursuing diploma degree in LIS are those students who did not make up to Cumulative GPA of 3.00 or those from other departments that want to further their studies in librarianship. Those pursuing masters degree are supposed to have completed their first degree (bachelor's or diploma degree) while those pursuing $\mathrm{PhD}$ degree are supposed to have completed masters' degree in LIS from different Universities that offered degree in librarianship in Nigeria. These Postgraduate students are expected to have acquired information literacy knowledge and skills from different universities in Nigeria where they did their first degree in Library and Information Science. In order words, they are supposed to be grounded in LIS courses especially the information literacy courses. LIS postgraduate students are expected to be information providers and educators but they cannot play such role effectively without, acquiring information literacy competencies through their university education. The acquired information literacy competencies will help LIS postgraduate students to teach the library users the necessary competencies needed to cope with information explosion in this era as well as help professes professionals goals.

As pointed out by Islam and Tsuji (2010), it is expected that LIS graduate students should acquire information literacy competencies during their undergraduate days in universities, a supposed part of their curriculum. Hence, Lamond \& White (2008) opined that,

it is expected that students graduating from university study will be equipped with not only discipline-based knowledge and skills but with more generic competencies that will allow them to operate as effective professionals and to continue to learn and develop through life in an autonomous and independent manner (p. 1).

From the foregoing, it is evident that one of the major objectives of university education is to produce graduates with lifelong learning abilities. Information Literacy is a recognized lifelong learning and graduate attribute (Lamond \& White, 2008); and has its root in library and information science (LIS). LIS students are acquiring university education for lifelong learning and to serve as information providers. In order to achieve these, university undergraduate's LIS curriculum is developed to ensure that the students acquire information literacy competencies. As information providers, LIS students are expected to have the information literacy competencies to enable them recognize when and why information is needed, where to find it, how to evaluate, use and communicate information ethically and legally. 
However, the researchers' preliminary observations and interaction with LIS graduate students from different universities in Nigeria raise some doubt on their possession of these; especially with reference to the utilization of the competencies for their academic activities. Furthermore, the researchers' close observation of LIS postgraduate students who work in the university libraries in some part Nigeria also raises the question on the availability of these competencies despite the expectation that they should employ such competencies for services to library users. Though some researchers have carried out studies on information literacy competencies possessed by LIS graduate students with different results, to the researchers' best of knowledge, little has been done to ascertain the information literacy competencies possessed by LIS postgraduate students in Nigeria, especially in the South East zone. It is therefore pertinent to carry out a research to find out the information literacy competencies possessed by LIS postgraduate students. Specifically, the study was designed to ascertain the information literacy knowledge possessed by the LIS postgraduate students and ascertain the level of information literacy skills possessed by the LIS postgraduate students. The study was guided by two hypothesis including:

1. There is no significant difference in the mean achievement scores of information literacy knowledge possessed by LIS Postgraduate students in Nnamdi Azikiwe University Awka and University of Nigeria Nsukka.

2. There is no significant difference in the mean rating of level of information literacy skills possessed by LIS Postgraduate students in Nnamdi Azikiwe University Awka and University of Nigeria Nsukka.

\section{Literature Review}

Globally so much has been written on information literacy knowledge and skills. SCONUL'S Seven Pillars of Information Literacy model forms the basis for discussing information literacy knowledge and skills in this study. In order words, SCONUL'S Seven Pillars of Information Literacy model frames this study. The United Kingdom's Society of College, National and University Libraries (SCONUL) published its information literacy model called the Seven Pillars of Information Literacy in 1999. They have been widely used in the United Kingdom and around the world (Webber, 2006). However, in 2011 the SCONUL working Group on Information Literacy updated and expanded the model in order to reflect more clearly the range of different terminologies and concepts which are now understood as information literacy. Information literate researchers according to SCONUL (2011) will demonstrate an awareness of how they gather, use, manage, synthesize and create information and data in an ethical manner and will have the information skills to do so effectively. In other words, this new model defines the core competencies which include knowledge and skills that are the goals of information literacy development in higher education, with each core competency called a "pillar". Within each "pillar" a researcher can develop from "novice" to "expert" as they progress through their research life, although, as the information world itself is constantly changing and developing, it is possible to move down a pillar as well as progress up it. The pillars are envisioned as a circle or cycle, rather than a sequence, and individuals can achieve different levels of complexity within each pillar. The seven pillars are:

$>$ Identify: A researcher is able to identify a need for information

$>$ Scope: A researcher can assess current knowledge and identify gaps

$>$ Plan: A researcher can construct strategies for locating information and data

$>$ Gather: A researcher can locate and access the information and data they need

$>$ Evaluate: A researcher can review the research process and compare and evaluate information and data

$>$ Manage: A researcher can organize information professionally and ethically

> Present: A researcher can apply the knowledge gained: presenting the results of their research, synthesizing new and old information and data to create new knowledge and disseminating it in a variety of ways.

Each pillar according to SCONUL (2011) is further described by a series of statements relating to a set of competencies. In other words, each pillar deals with combination of knowledge and skills towards identifying a need for information; assessing current knowledge and identifying gaps; constructing strategies for locating information and data; locating and accessing the information and data needed; reviewing the research process and comparing and evaluating information and data; and organizing information professionally and ethically.

SCONUL'S Seven Pillars of Information Literacy model as discussed so far frames this study. This is because it explained in details what are expected from students or individuals in order to attain the information literacy competencies. In other words, it deals with attributes of information literate person which is the combination of knowledge and skills that make up information literacy competencies. This theoretical model is related to this study because it explained in details the information literacy knowledge and skills which the present study intends to measure.

Town's presentation at the first International Conference on Information Technology and Information Literacy in Glasgow, in an attempt to explain information literacy knowledge stated that " information literacy is knowledge rather than simple skill, achieved by education rather than training, created through partnership 
between professionals and is a lifelong endeavour that is contextual in field and service access" (Town, 2002).. The eleven stages of information literacy knowledge according to Horton(2007) include: realize that a need or problem exists that requires information and its satisfactory resolution; know how to accurately identify and define the information needed to meet the need, solve the problem, or make the decision; know how to determine whether the needed information exists or not, and if it does not, know how to create, or cause to be created the unavailable information (also referred to as "creating new knowledge"); know how to find the needed information if you have determined that it does, indeed, exist; know how to create, or cause to be created, unavailable information that you need; sometimes called "creating new knowledge."; know how to fully understand found information, or know where to go for help if needed to understand it; know how to organize, analyze, interpret and evaluate information, including source reliability; know how to communicate and present the information to others in appropriate and usable formats and mediums; know how to utilize the information to solve a problem, make a decision or meet a need; know how to preserve, store, reuse, record and archive information for future use; know how to dispose of information no longer needed, and safeguard information that should be protected. Consequently, Newton (2005) opined that information literacy knowledge has to do with knowing: when you have a need for information; the resources available to you; how to find information; the need to evaluate results; how to work with or exploit results; the ethics and responsibility of using information; how to communicate and share your research finding; and how to manage your research findings. Furthermore, the University of Calgary Library (n.d) looking at information literacy knowledge stated that information literacy knowledge focuses on: recognization of the need for information; knowing how to access information; understanding how to evaluate information; knowing how to synthesize information; and knowing how to communicate information. It can then be synthesize that information literacy knowledge has to with the understanding of how to: recognize a need for information; determine the extent of information needed; access information efficiently; critically evaluate information and its sources; classify, store, manipulate and redraft information collected or generated; incorporate selected information into knowledge base; use information effectively to learn, create new knowledge, solve problems and make decisions; access and use information ethically and legally.

On the other hand information literacy skills according to Mitchell (n.d) are specific tasks or procedures which serve information need. Ranaweera (2008) opined that "information literacy skills empower the people with critical skills which will help them to become independent lifelong learners. These skills will enable people to apply their knowledge from familiar environment to the unfamiliar". Information literacy skills as pointed out by Kovalik, Jesen, Schloman and Tipton (2010) refers to an individual's ability to recognize when there is a need for information, and to be able to identify, locate, evaluate, and effectively use that information for the issue or problem at hand. Mitchell (n.d) indicated that Information literacy skills are exemplified by ideas such as the ability to discover, retrieve, and use information, the ability to manage information, and the ability to make critical choices about information resources. Ojedokun (2007) posited that information literacy skills in all disciples requires an individual to be able to define problem; initiate a plan to find information; locate and access resources; use the information; synthesize information; and carry out some forms of evaluation. On this regard, Bruce (2003) pointed out that information literacy skills deals with the ability to access, evaluate, organize and use information in order to learn, solve problem, and make decisions in formal and informal learning contexts, at work, at home and educational settings. Andretta (2005) study of information literacy skills identifies higher and lower order thinking associated with information literacy skills. Lower order thinking according to Andretta involves activities such as the identification of keywords, synonyms and related terms when a search strategy is formulated. Higher-order thinking at the other end of the scale involves abstraction to develop a new hypothesis.

The International Federation of Library Associations and Institutions (IFLA) information literacy standards as noted by Lau (2006) grouped information literacy skills under three basic information literacy components which include; access, evaluate and use. The three basic information literacy components are further categorized with some features.

The review has unveiled a very sharp overlap between information literacy skills and knowledge. Knowledge can be considered a stepping stone to the skill.

Islam and Tsuji (2010) who carried out a survey to assess the information literacy competency of graduate students of Information Science and Library Management in the University of Dhaka (ISLM), Bangladesh, in order to determine their strength and weakness. It was discovered that students had limited skills in the area of information literacy, as it is not discussed extensively in their course curriculum.

In his study of students' the information literacy competency at the Department of Library and Information science, Faculty of Humanities, University of Indonesia Irawti (2009) grouped the information literacy of the students as very good. Sumpter (2006) found in his study of information literacy competencies of students in the School of Public Health at the University of North Carolina that the graduate students demonstrated a high proficiency in information literacy competencies, but a significant number of graduate students had important weaknesses in them 
As part of revised accreditation standards, Singh (2005) conducted a survey study on information literacy competencies of students in Journalism and Mass communication at universities in the United States to assess the faculties' perceptions of their students' information literacy skills as defined by Association of College and Research Libraries (ACRL) Standards and Revised Accreditation Standard. The result was that undergraduate information literacy competencies were mostly adequate or poor.

The review has revealed a knowledge gap in the area of information literacy competencies of students in Nigeria. Hence the research was designed to fill the gap.

\section{Method}

Descriptive survey design was adopted for the study. The study was carried out in federal universities in South East Zone of Nigeria with focus on those offering library science programme at the postgraduate level. The Universities include Nnamdi Azikiwe University Awka and University of Nigeria Nsukka The population comprised seventy two (72) students which included all 2011/2012 PhD and Masters degree students from the Departments of LIS in Nnamdi Azikiwe University, Awka and University of Nigeria, Nsukka. Data was collected using Achievement Test and Information Literacy Questionnaire. Achievement test was used to test their knowledge level while Questionnaire was used for their level of information literacy skills. In the achievement test, respondents were exposed to twenty multipurpose questions to test their knowledge of the four elements of information literacy namely: understanding: the need for information, how to locate information, how to evaluate information, and how to use information. The test has a total score of $100 \%$. Only those who scored $50 \%$ were considered to have passed the test. The questionnaire was designed on a four point scale ranging from scale four for highly skilled, three for moderately skilled, two for weakly skilled and one for not skilled. The essence was to test their level of information literacy skill. . Data obtained from the study were analyzed using descriptive and inferential statistics. Percentages, frequencies and mean rating were used to answer research questions while t-test was used to test hypothesis. The pass mark for achievement test was 50 percent. This was derived by awarding five (5) marks to each question with correct answer and the scores were converted to percentages. Likewise, midpoint for responses in four (4) point scale was 2.50 which was the mean of the four scales derived as follows, $4+3+2+1=10 / 4=2.50$.

\section{Result}

The results were presented to actualize the purpose of the research.

4.1 Information literacy knowledge possessed by LIS postgraduate students

LIS postgraduate students were required to answer questions on the achievement test which will serve as a measure of their information literacy knowledge. The measure was based on their understanding of the need for information, how to locate, evaluate and use information. The summary of their score is presented on Table 1 .

Table 1 shows LIS postgraduate students' scores based on 20 achievement test questions which they were asked in order to find out their understanding of the need for information, how to locate, evaluate and use information. From the results in Table 1, items 1 to 4 covers questions on understanding the need for information with percentage scores ranging from 90 to 97 , the average percentage score of $95 \%$ shows that LIS postgraduate students understand when they need information. Items 5 to 12 covers questions on understanding how to locate information with percentage scores ranging from 61 to 99 , the average percentage score of $87 \%$ shows that LIS postgraduate students understand how to locate information. Items 13 to 16 covers questions on understanding how to evaluate information with percentage scores ranging from 72 to 92 , the average percentage score of $82 \%$ shows that LIS postgraduate students understand how to evaluate information. Items 17 to 20 covers questions on understanding how to use information with percentage scores ranging from 81 to 92 , the average percentage score of $88 \%$ shows that LIS postgraduate student understand how to use information. 
Table 1: Students Response to Test on their: Understanding of the Need for Information, How to Locate, Evaluate and Use Information

\begin{tabular}{|c|c|c|}
\hline Questions & Frequency (No. of students that passed the test) & Percentage $(\%)$ Scores \\
\hline & Understanding the Need for Information & \\
\hline 1. & 70 & 97 \\
\hline 2. & 68 & 94 \\
\hline 3. & 70 & 97 \\
\hline \multirow[t]{3}{*}{4.} & 65 & 90 \\
\hline & Average Percentage & 95 \\
\hline & Understanding how to Locate Information & \\
\hline 5. & 71 & 99 \\
\hline 6. & 70 & 97 \\
\hline 7. & 60 & 83 \\
\hline 8. & 65 & 90 \\
\hline 9. & 70 & 97 \\
\hline 10. & 63 & 88 \\
\hline 11. & 44 & 61 \\
\hline \multirow[t]{3}{*}{12.} & 60 & 83 \\
\hline & Average Percentage & 87 \\
\hline & Understanding how to Evaluate Information & \\
\hline 13. & 52 & 72 \\
\hline 14. & 56 & 78 \\
\hline 15. & 62 & 86 \\
\hline \multirow[t]{3}{*}{16.} & 66 & 92 \\
\hline & Average Percentage & 82 \\
\hline & Understanding how to Use Information & \\
\hline 17. & 62 & 86 \\
\hline 18. & 58 & 81 \\
\hline 19. & 68 & 94 \\
\hline \multirow[t]{2}{*}{20.} & 66 & 92 \\
\hline & Average Percentage & 88 \\
\hline
\end{tabular}

The average percentage scores of LIS postgraduate students' information literacy knowledge as measured based on understanding the need for information, how to locate, evaluate and use information is presented in Figure 1.

\section{Information Literacy Knowledge}

Percentage Scores

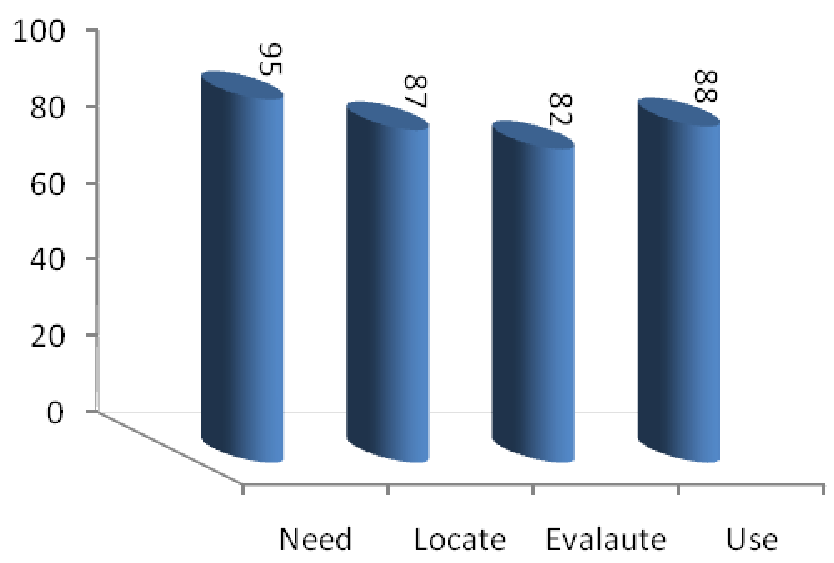

Figure 1: Mean Percentage (\%) Scores of the LIS Postgraduate Students on Achievement Test for the Various Elements of Information Literacy Knowledge

From Figure 1, the students average percentage scores for information literacy knowledge represented by need, locate, evaluate and use are 95, 87, 82 and 88 respectively. This shows that LIS postgraduate students possessed 
information literacy.

\section{4..2 Level of information literacy skills possessed by LIS postgraduate students}

The mean scores of LIS postgraduate students' responses on the level of information literacy skills is measured based on their ability to identify the Need, Locate and Access, Evaluate and Use information. The students were required to indicate their level to which they are skilled in the mentioned information literacy skilled. The mean score of their responses is presented in Table 2.

Table 2: Mean Scōes of of LIS Postgraduate Students' Response on the Level of Ability to: Identify the Need, Locate and Access Information; Evaluate and Use Information

\begin{tabular}{|c|c|c|c|}
\hline $\mathrm{S} / \mathrm{n}$ & Items & $\operatorname{Mean}(\times \overline{)}$ & Decision \\
\hline $\begin{array}{l}1 . \\
2 .\end{array}$ & $\begin{array}{l}\text { Ability to Identify the Need, Locate and Access Information } \\
\text { Formulating question base on my specific information need } \\
\text { Using several sources to increase familiarity with my topic }\end{array}$ & $\begin{array}{l}3.51 \\
3.54\end{array}$ & $\begin{array}{l}\text { HS } \\
\text { HS }\end{array}$ \\
\hline 3. & $\begin{array}{l}\text { Effectively using library catalogues [both card catalogue and online public } \\
\text { access catalogue (OPAC)] }\end{array}$ & 3.29 & MS \\
\hline 4. & Using abstracting and indexing journal & 3.31 & MS \\
\hline 5. & $\begin{array}{l}\text { Using the bibliography or reference list on the book to find other documents on } \\
\text { the topic }\end{array}$ & 3.39 & MS \\
\hline 6. & $\begin{array}{l}\text { Using encyclopedia to understand a background information to a particular } \\
\text { topic }\end{array}$ & 3.50 & HS \\
\hline 7. & $\begin{array}{l}\text { Finding all the documents about a particular author in the library catalogue, by } \\
\text { doing access points search either by author, title, subject or keywords }\end{array}$ & 3.40 & MS \\
\hline 8. & Using Google scholar as Google features to find a research article online & 3.47 & MS \\
\hline 9. & $\begin{array}{l}\text { Finding more documents on my topics online, by combining synonyms in my } \\
\text { search by using the Boolean operator "OR" }\end{array}$ & 3.11 & MS \\
\hline 10. & $\begin{array}{l}\text { Narrowing my search on a particular topic, by using the Boolean operator } \\
\text { "AND" }\end{array}$ & 3.06 & MS \\
\hline 11. & $\begin{array}{l}\text { Removing unwanted documents from my search, by using the Boolean } \\
\text { operator "NOT" }\end{array}$ & 3.08 & MS \\
\hline \multirow[t]{3}{*}{12.} & $\begin{array}{l}\text { Formulating right keywords in searching for information } \\
\text { Online }\end{array}$ & 3.29 & MS \\
\hline & Grand Mean & 3.33 & MS \\
\hline & Ability to Evaluate Information & & \\
\hline 13. & Competently evaluate information no matter the source & 3.09 & MS \\
\hline 14. & Evaluate print sources based on its criterion & 3.22 & MS \\
\hline \multirow[t]{3}{*}{15.} & Evaluate online sources based on its criterion & 3.21 & MS \\
\hline & Grand Mean & 3.17 & MS \\
\hline & Ability to Use Information & & \\
\hline 16. & Selecting materials and summarizing them in my own words for personal use & 3.54 & HS \\
\hline 17. & Preserving and storing information for future use & 3.49 & MS \\
\hline 18. & Using acquired information as a lead to produce an article or thesis & 3.53 & HS \\
\hline 19. & $\begin{array}{l}\text { Communicating and presenting information to others in appropriate and usable } \\
\text { format }\end{array}$ & 3.39 & MS \\
\hline \multirow[t]{2}{*}{20} & Competently cite and acknowledge other people's work that I used & 3.63 & HS \\
\hline & Grand Mean & 3.52 & HS \\
\hline
\end{tabular}

Note. Highly skilled (HS) $3.50-4.0$, Moderately(MS) $3.0-3.49$, Weakly skilled(WS) $2.0-2.99, \quad$ Not skilled(NS) $1.0-1.99$ 
From the results in Table 2 revealed that the items on the ability to identify the need, locate and access information were rated at the mean ranging from 3.06 to 3.54 . The mean ratings of 3.50 and above show that LIS postgraduate students are highly skilled in those areas of skills especially on their ability to use several sources to increase familiarity with their topics (that is, where they have the highest score of 3.54). Also, the mean ratings of 3.47 and below indicate that the students are moderately skilled in other areas of skills. The grand mean rating of 3.33 indicates that LIS postgraduate students are moderately skilled in identifying the need, locating and accessing information. The Items on ability to evaluate information with mean ratings ranging from 3.09 to 3.22 , the grand mean rating of 3.17 shows that LIS postgraduate students are moderately skilled in evaluating information. The mean rating on the students ability to used information ranges between 3.39 to 3.54. The mean ratings of 3.53 and above shows that LIS postgraduate students are highly skilled in those areas of skills especially in the ability to cite other peoples work effectively where they have the highest mean rating of 3.63. The mean ratings of 3.39and 3.49 show that the students are moderately skilled in those areas of skills. The grand mean of 3.52 indicates that LIS postgraduate students are highly skilled in their ability to use information.

The grand mean ratings of LIS postgraduate students' level of information literacy skills as measured based on their ability to Identify the need, Locate and Access, Evaluate and Use information is presented in Figure 2.

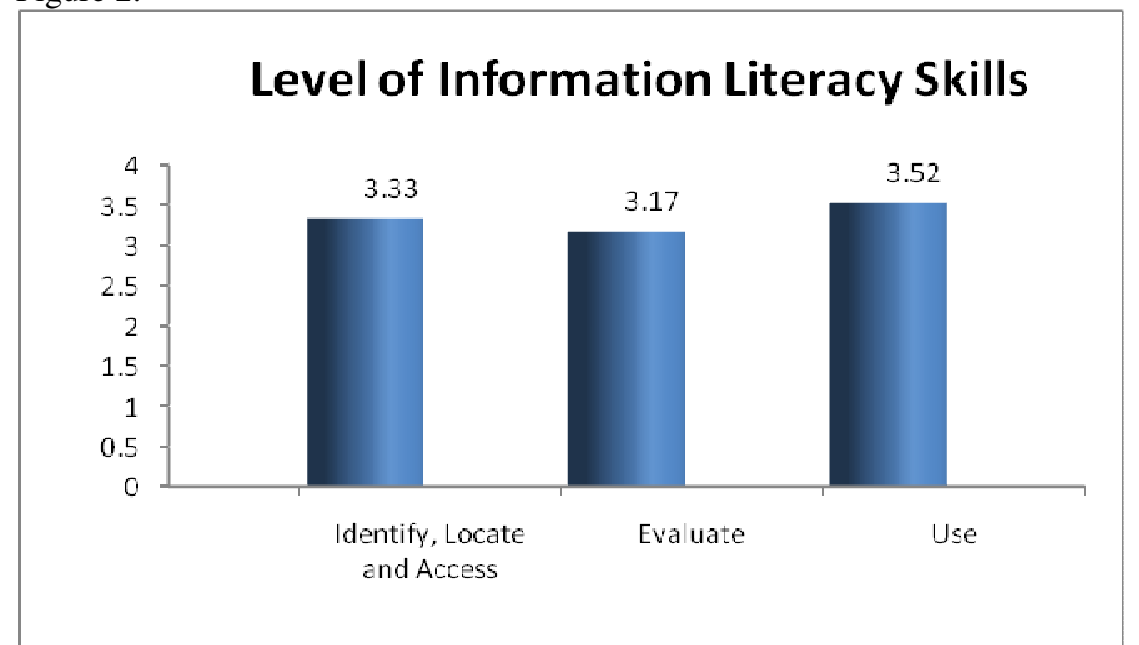

Figure 2: Level of Information Literacy Skills Possessed by LIS Postgraduate Students

Note: Highly Skilled (HS) 3.50 - 4.0, Moderately Skilled (MS) 3.0 - 3.49, Weakly Skilled (WS) 2.0 - 2.99, Not Skilled (NS) $1.0-1.99$

From Figure 2, the students' ability to identify the need, locate and access information has mean rating of 3.33, ability to evaluate information has mean rating of 3.17 and ability to use information has mean rating of 3.52. This shows that LIS postgraduate students are highly skilled on ability to use information and moderately skilled on ability to identify the need, locate and access information as well as ability to use information. The mean for the three set of skills which include the ability to identify the need, locate and access (3.33), ability to evaluate (3.17) and ability to use information (3.52) is 3.34. This implies that LIS postgraduate students possessed moderate level of information literacy skills.

Two research hypotheses were tested at 0.05 level of significance using t-test statistical tool. The hypotheses include firstly:

There is no significant difference in the mean achievement scores of information literacy knowledge possessed by LIS Postgraduate students in Nnamdi Azikiwe University Awka and University of Nigeria Nsukka.

Table 3 : Summary of t-test Analysis on Difference in the Mean Achievement Scores of Information Literacy Knowledge Possessed by LIS Postgraduate Students in Nnamdi Azikiwe University Awka and University of Nigeria Nsukka

\begin{tabular}{llllllllll}
\hline LIS Postgraduate (PG) Students & $\mathrm{N}$ & $\bar{x}$ & SD & A & df & $t$-cal & t-crit & Decision
\end{tabular}

LIS PG Students in NAU

LIS PG Students in UNN
$35 \quad 88.43$

$37 \quad 86.62$

\subsection{6}

$\begin{array}{llll}0.05 & 70 & 2.48 & 1.98\end{array}$

Reject 
The test for significance is show in Table 3 , the $\mathrm{t}$-calculated is 2.48 while t-critical is 1.98 . At 0.05 level of significance and 70 degree of freedom, $t$-calculated value is greater than $t$-critical value. Since tcalculated value of 2.48 is greater than t-critical value of 1.98, the null hypothesis is therefore rejected. The researcher then concludes that there is a significant difference in the mean achievement scores of information literacy knowledge possessed by LIS Postgraduate students in Nnamdi Azikiwe University Awka and University of Nigeria Nsukka.

Secondly, there is no significant difference in the mean rating of level of information literacy skills possessed by LIS Postgraduate students in Nnamdi Azikiwe University Awka and University of Nigeria Nsukka. The result of the test is presented in Table 4.

Table 4: Summary of t-test Analysis on Difference in the Mean Rating of Level of Information Literacy Skills Possessed by LIS Postgraduate Students in Nnamdi Azikiwe University Awka and University of Nigeria Nsukka

\begin{tabular}{|c|c|c|c|c|c|c|c|c|}
\hline LIS Postgraduate (PG) Students & $\mathrm{N}$ & $\bar{x}$ & SD & A & df & t-cal & t-crit & Decisio \\
\hline \multirow[t]{2}{*}{ LIS PG Students in UNN } & 37 & 67.81 & 9.86 & & & & & \\
\hline & & & & 0.05 & 70 & 9.25 & 1.98 & Reject \\
\hline LIS PG Students in NAU & 35 & 65.83 & 6.78 & & & & & \\
\hline
\end{tabular}

In Table 4, the t-calculated is 9.25 while t-critical is 1.98 . At 0.05 level of significance and 70 degree of freedom, t-calculated value of 9.25 is greater than t-critical value of 1.98; the null hypothesis is therefore rejected. Thus, there is a significant difference in the mean rating of level of information literacy skills possessed by LIS Postgraduate students in Nnamdi Azikiwe University Awka and University of Nigeria Nsukka.

\section{Discussion of Results}

The result that LIS postgraduate students possessed information literacy knowledge. They possessed information literacy knowledge because they understand when and why they need information, where to find it, and how to evaluate, use and communicate it ethically and legally. That is, LIS postgraduate students have knowledge of when they need information, how to locate, evaluate and use information ethically and legally. This is founded on the definition of information literacy knowledge by Newton (2005) that information literacy knowledge deals with knowing: when you have a need for information; the resources available to you; how to find information; the need to evaluate results; how to work with or exploit results; the ethics and responsibility of using information; how to communicate and share your research finding; and how to manage your research findings. The result of this study is in line with that of Sumpter (2006) who found that LIS postgraduate students demonstrated high proficiency in information literacy knowledge. However, this result differs from the finding of Islam and Tsuji (2010), who found that LIS graduate students are not in good position as regards their understanding of information literacy. The present result may be different from that of Islam and Tsuji because, it studied LIS postgraduate students while that of Islam and Tsuji studied LIS graduating students. Therefore, the result that LIS postgraduate students possessed information literacy knowledge is not misleading.

Furthermore, the result reveals that LIS postgraduate students possessed moderate level of information literacy skills. This is because they are moderately skilled in locating and accessing information, evaluating information and highly skilled in using information. This implies that LIS postgraduate students are moderately skilled in their ability to locate and access information, evaluate, use and communicate information ethically and legally. This is as posited by Ojedokun (2007) that information literacy skills in all disciples requires an individual to be able to define problem; initiate a plan to find information; locate and access resources; use the information; synthesize information; and carry out some forms of evaluation. This result is line with the findings of Islam and Tsuji (2010), who found that LIS graduate students had limited skills in the area of information literacy. This is not encouraging because LIS postgraduate students are expected to teach other students information literacy skills. However, it is doubtful if they can do that with their level of information literacy skills being moderate. Moreover, the result of this study differs from that of Sumpter (2006), Irawati (2009) and Singh (2005). Sumpter found that LIS postgraduate students demonstrated high proficiency in information literacy skills. Irawati study also grouped the students' information literacy skills as very good. Irawati findings may not be reliable because only 5 students were used for the study. Finally, Singh study found that graduate students met Association of College \& Research Libraries (ACRL) standards. In other words, meeting the ACRL standard means that the students possessed high level of information literacy skills. The result of this present study is not misleading because other findings that were not in support of its finding were carried out in other countries (mostly in developed countries, especially in United States of America). 


\section{Conclusion}

The LIs postgraduate students of the studied Nigerian universities are equipped for life long learning in view of the fact that they possess information literacy knowledge which is revealed in their understanding of when and why they need information, where to find it, how to evaluate it, how to use and communicate it ethically and legally. The students posses moderate level of information literacy skill since they have the ability to locate and access information, evaluate and use information ethically and legally.

It is therefore evident that their curriculum is yielding the needed results, and LIS educators and schools are producing graduates who are qualified to apply the required knowledge. However there is the need for more practical aspect of information literacy through industrial training and internships in order to enhance the information literacy skills of the students .

\section{References}

Andretta, S. (2005). Information literacy: A practitioner's guide. Oxford: Chandos publishing

Anunobi, C., \& Nwabueze, A. (2010). Migrating from the traditional to the digital library environment: Whither Nigerian information professionals. Proceedings of second professional summit on information science and technology (PSIST), (pp. 185-191). Nsukka: University of Nigeria.

Bruce, C. S. (2002). Information literacy as a catalyst for educational change: a background paper. White paper prepared for UNESCO, the US NCLIS and National Forum for Information Literacy. Retrieved from http://www.nclis.gov/libinter/

Bruce, C. (2003). Seven faces of information literacy: Towards inviting students into new experiences. Retrieved from http://www.bestlibrary.org/digital/files/bruce.pdf

Bundy, A. (Ed.). (2004). Australian and New Zealand information literacy framework: Principles, standards and practice, $2^{\text {nd }}$ edition. Adelaide: Australian and New Zealand Institute for Information Literacy (ANZIIL). Retrieved from http://www.caul.edu.au/info-literacy/InfoLiteracy Framework.pdf

Charted Institute of Library and Information Professionals. (2004). Information literacy: Definition. London: CILIP. Retrieved from http://www.cilip.org.uk/professionalguidance/informationliteracy/definition/

Horton, F.W. (2007). Understanding information literacy: A primer. Paris: United Nations Educational, Scientific and Cultural Organization (UNESCO). Retrieved from http://www.unesco.org/webword

Irawti, I. (2009). Information literacy competency of library and information science students at the Faculty of Humanities University of Indonesia. Asia-pacific Conference on Library and Information Education and Practice. Retrieved from http://www.tulips.tsukuba.ac.jp/dspace/bitstream/2241/ 102592/21p_7.pdf

Islam, M. A., \& Tsuji, K., (2010). Assessing information literacy competency of information science and library management graduate students of Dhaka University. Journal of the International Federation of Library Associations and Institutions (IFLA), 36 (4), 300-316. doi:10./177/0340035210388243

Johnston, B., \& Webber, S. (2003). Information literacy in higher education: A review and case study. Studies in Higher Education, 28(3), 335-352.

Kovalik, C. L., Jensen, M. L., Schloman \& Tipton, M. (2010). Information literacy collaboration, and teacher education. Communication and Information Literacy, 4,145-169. Retrieved from http://www.comminfolit.org/index.php

Lamond, H., \& White, B. (2008). Issues in equivalence: Information literacy and the distance students. Paper presented at DEANZ (Distance Education Association of New Zealand) Conference, (pp. 1-12). Retrieved from http://muir.massey.ac.nz/handle/10179/680

Lau, J. (2006). Guidelines on information literacy for lifelong learning. Retrieved from http://www.ifla.org/files/information-literacy/publications/ifla-guidelines-en.pdf

Mitchell, E. (n.d.). Information literacy: Theoretical foundation. Retrieved on February 12, 2012 from http://erikmitchel.info/uploaded_files/dissertation/1_information_literacy_mitchel.pdf

Newton, A. (2005). What is information literacy? Retrieved from http://www.ldu. leeds.ac.uk/news/events/documents/informationliteracy.pdf

Ojedokun, A. A. (2007). Information literacy for tertiary education students in Africa. Ibadan: Third world information services limited.

Ranaweera, P. (2008). Importance of information literacy skills for an information literate society. In proceedings NACLIS. Retrieved from http://eprints.rclis.org/archive/00014146/

SCONUL. (2011). The SCONUL seven pillars of information literacy. A research lens for higher education. SCONUL working group of information literacy. Retrieved from http://www.sconul.ac.uk/groups/information_literacy/seven_pillars.html

Shenton, A. K. (2009). Information literacy and scholarly investigation: A British perspective. Journal of the 
International Federation of Library Associations and Institutions, 35(3), 209-291. Retrieved from http://ifl.sagepub.com

Singh, A. B. (2005). A report on faculty perceptions of students' information literacy competencies in journalism and mass communication programs: The ACEJMC survey. College and Research Libraries, 66(4), 294-310.

Sumpter, J. (2006). A baseline assessment of information literacy competencies of students in the school of public health at the University of North Carolina at Chapel Hill. (Master's thesis, University of North Carolina). Retrieved from http://cdr.lib.unc.edu/indexablecontent\%3Fid\%3Duid:e7F91Fb6-2663-412591d7-a30164e22a8e\%26ds\%3DATA_FILE\%26d1\%3Dtrue839

Town, J. S. (2002). Information literacy: Definition, measurement \& impact. Paper presented at the International conference on IT and information literacy. Abstract retrieved from http://www.iteu.gla.ac.uk/elit/itilit2002/papers/ab15.html

United States National Commission on Library and Information Science. (2003). The Prague declaration: Towards an information literate society. Retrieved from http://www.nclis.gov/libinter/infolitconf\&meet/postinfolitconf\&meet/ PragueDeclaration.pdf

University of Calgary Library. (n.d.). Information: Definitions and competencies. Retrieved from http://www.ucalgary.ca/lib-old/ILG/workdef.html

University of Liverpool Teaching and Learning Committee. (2007). Information literacy standards. Retrieved from http://www.liv.ac.uk/library /using/literacy.pdf

Webber, S. (2006). Information literacy standards and statements. Retrieved from http://dis.shef.ac.uk/literacy/standards.htm

Williams, D., \& Coles, L. (2007). Teachers' approaches to finding and using research evidence: An information literacy perspective. Educational Research, 49(2), 185-206. doi: 10.1080/00131880701369719

Wilson, L. A. (2001). Information literacy: fluency across and beyond the university. In B. I. Dewey (Ed.), Library User Education: Powerful learning, powerful partnership, 
The IISTE is a pioneer in the Open-Access hosting service and academic event management. The aim of the firm is Accelerating Global Knowledge Sharing.

More information about the firm can be found on the homepage:

http://www.iiste.org

\section{CALL FOR JOURNAL PAPERS}

There are more than 30 peer-reviewed academic journals hosted under the hosting platform.

Prospective authors of journals can find the submission instruction on the following page: http://www.iiste.org/journals/ All the journals articles are available online to the readers all over the world without financial, legal, or technical barriers other than those inseparable from gaining access to the internet itself. Paper version of the journals is also available upon request of readers and authors.

\section{MORE RESOURCES}

Book publication information: http://www.iiste.org/book/

Academic conference: http://www.iiste.org/conference/upcoming-conferences-call-for-paper/

\section{IISTE Knowledge Sharing Partners}

EBSCO, Index Copernicus, Ulrich's Periodicals Directory, JournalTOCS, PKP Open Archives Harvester, Bielefeld Academic Search Engine, Elektronische Zeitschriftenbibliothek EZB, Open J-Gate, OCLC WorldCat, Universe Digtial Library, NewJour, Google Scholar

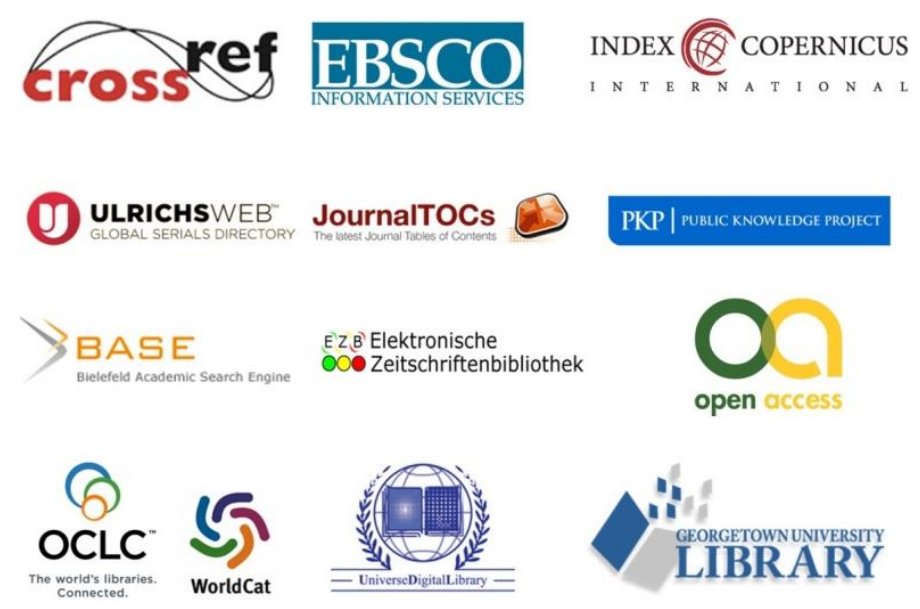

